\title{
Kebersyukuran Dan Kebahagiaan Pada Wanita Yang Bercerai di Aceh
}

\author{
Dian Eriyanda dan Maya Khairani \\ Fakultas Kedokteran, Program Studi Psikologi; \\ Universitas Syiah Kuala Darussalam \\ e-mail: dianeriyanda@ymail.com; khairani.maya@unsyiah.ac.id
}

\begin{abstract}
The number of divorce cases in Aceh increases every year. With most divorce cases filed by the wife. In light of divorce, divorcées still needs a sense of gratitude to go on with life. Gratitude can manifest positive feelings such as happiness. This study aims to determine the correlation between gratitude and happiness on divorcées in Aceh. This study was done by quantitative approach with purposive sampling technique. The sample in this study are 247 divorcées. Data analysis using the Spearman test showed correlation coefficient of 0,650 with $p<0,10$. The hypothesis was confirmed so it can be concluded that there's a significant positive correlation between gratitude and happiness on divorcées in Aceh. This shows that on divorcées in Aceh, the more grateful therefore the happier. The result of this study also shows that divorcées in Aceh falls under the high category for gratitude and happiness.
\end{abstract}

Keywords: Gratitude, Happiness, Divorcées, Aceh.

\section{PENDAHULUAN}

Pasca Tsunami 2004 di Aceh, angka perceraian meningkat tajam hingga tiga kali lipat dan didominasi oleh gugatan dari pihak wanita (Mahkamah Syar'iyah Aceh, 2016). Perceraian sendiri merupakan sebuah perpisahan dengan bentuk resmi yang dialami oleh suami dan istri, sehingga setelah resmi bercerai tidak ada lagi tugas dan kewajiban sebagai suami dan istri (Dariyo, 2004). Pada tahun 2013, terdapat 4.357 kasus permohonan perceraian yang terdaftar di 20 Mahkamah Syar'iyah Aceh dan 3.093 permohonan diantaranya diajukan oleh pihak wanita. Pada tahun 2014, angka perceraian meningkat menjadi 4.801 kasus permohonan perceraian dan 3.457 permohonan diantaranya diajukan oleh pihak wanita. Pada tahun 2015 angka perceraian kembali meningkat, dari 5.280 permohonan perceraian, ternyata 3.850 permohonan diantaranya diajukan oleh pihak wanita (Mahkamah Syar'iyah Aceh, 2016). Dari keseluruhan kabupaten dan kota di Aceh, Lhoksukon dan Kuala Simpang memiliki kasus cerai gugat tertinggi sepanjang tahun 20132015.

Angka perceraian yang terus meningkat dapat dikarenakan beberapa penyebab perceraian yaitu adalah perbedaan harapan antara perempuan dan lakilaki dan juga ketidaksiapan suami istri dengan penyesuaian dalam membangun komitmen pernikahan (Papalia, Old \& Feldman, 2009). Adapun faktor utama penyebab perceraian di Aceh menurut Mahkamah Syar'iyah (2016) sepanjang tahun 2013 sampai dengan 2015 adalah tidak adanya keharmonisan dalam rumah tangga. Menurut Markam, Rhoades, Stanley, Ragan dan Whitton (2010) kualitas komunikasi antara suami istri juga dapat menjadi faktor penyebab perceraian dalam rumah tangga. Tanpa adanya komunikasi interpersonal yang baik antara suami dan istri maka keharmonisan dalam pernikahan akan sulit didapatkan (Dewi \& Sudhana, 2013). 
Hasil penelitian Nur'aeni dan Dwiyanti (2009) menunjukkan bahwa perempuan yang bercerai dan berubah status menjadi janda maka akan mengalami perasaan minder, malu, sedih, sakit hati, namun dapat juga merasakan lega, senang, dan bahagia. Keadaan hidup dan kegiatan yang sengaja dilakukan dapat memengaruhi kebahagiaan individu (Carr, 2011). Pada wanita bercerai, didapatkan perasaan lega dan senang yang mana perasaan tersebut merupakan faktor internal kebahagian yaitu emosi positif masa lalu yang didalamnya mencakup kelegaan, kepuasan, kesuksesan, kedamaian dan juga kebanggaan (Seligman, 2002). Ada beberapa hal yang dapat membuat individu bahagia (Patnani, 2012), seperti masalah yang dihadapi tidak dibuat rumit, merasa optimis, dan juga bersyukur (Rostiana \& Koesma, 2009). Kebersyukuran merupakan hal yang menyenangkan dan dihubungkan dengan emosi positif seperti kepuasan, kebanggaan, harapan dan juga kebahagiaan (Emmons \& McCullough, 2003). Penelitian Anggaraini, Andayani dan Karyanta (2013) menemukan bahwa individu yang bersyukur akan dengan mudah merasakan kebahagiaan.

Kebersyukuran dapat diartikan sebagai kecenderungan umum untuk menyadari dan merespon dengan emosi bersyukur terhadap kebaikan orang lain dalam pengalaman positif dan apa yang diperoleh individu (McCullough, Emmons, \& Tsang, 2002). Rasa syukur yang dialami wanita bercerai dapat dilihat sebagai bentuk perilaku umum yang dapat dimiliki setiap orang (Putra, 2014). Mutia, Subandi dan Mulyati (2010) menyebutkan bahwa mampu berfikir positif merupakan salah satu gambaran dari individu yang bersyukur. Kebersyukuran dapat dimanifestasikan dalam perasaan-perasaan positif yang merupakan senang dan bahagia (Hambali, Meiza \& Fahmi, 2015). Anggoro dan Widhiarso (2010) merumuskan kebahagiaan dengan pendekatan indigenous psychology sehingga mendefinisikan kebahagian sebagai sebuah proses pemenuhan rasa atau ikatan keluarga juga prestasi atau pencapaian yang diperoleh oleh individu dan relasi sosial yang baik serta dapat terpenuhinya kebutuhan spiritual individu yang didasarkan pada afek positif.

Adapun tujuan dari penelitian ini yaitu untuk melihat hubugan antara kebersyukuran dan kebahagiaan pada wanita yang bercerai di Aceh.

\section{METODE}

Penelitian ini menggunakan metode penelitian kuantitatif dengan jenis penelitian korelasional. Responden yang diambil dalam penelitian ini berjumlah 247 orang dengan karakteristik sebagai berikut: (a) berusia 20-40 tahun saat mengalami perceraian, (b) perceraian terjadi minimal di usia pernikahan 5 tahun; (c) wanita yang menggugat cerai, (d) menerima putusan cerai pada rentang tahun 2013-2015 di Mahkamah Syar'iyah Lhoksukon dan Kuala Simpang, (e) berstatus janda.

Pengumpulan data dalam penelitian ini menggunakan metode non probability sampling dengan teknik purposive sampling. Peneliti terlebih dahulu mendata jumlah angka perceraian di masing-masing daerah, setelah data didapatkan selanjutnya peneliti mendatangi masing-masing kediaman subjek untuk pengumpulan data. Adapun alat ukur yang digunakan dalam penelitian ini yaitu adaptasi dari The Gratitude Questionnaire- 6 (GQ-6) oleh McCullough, Emmons dan Tsang (2002) dan Skala Kebahagiaan Berbasis Pendekatan Indigenous Psychology oleh Anggoro dan Widhiarso yang telah dimodifikasi (2010).

The Gratitude Questionnaire- 6 (GQ-6) terdiri dari 6 butir pernyataan yang disusun dalam Bahasa Inggris, sehingga pada penelitian ini dilakukan 
proses adaptasi ke dalam Bahasa Indonesia. Proses adaptasi dimulai dari penerjemahan ke dalam Bahasa Indonesia kemudian versi Bahasa Indonesia divalidasi melalui proses expert review yang bertujuan untuk memeriksa kesesuaian bahasa yang digunakan. The Gratitude Questionnaire- 6 (GQ-6) menggunakan penskalaan likert yang terdiri dari kelompok pernyataan favorable dengan pilihan jawaban dan penilaian skor, yaitu: sangat tidak setuju diberi nilai 1 , tidak setuju diberi nilai 2 , kurang setuju diberi nilai 3, netral diberi nilai 4 , sedikit setuju diberi nilai 5 , setuju diberi nilai 6 , dan sangat setuju diberi nilai 7 . Sementara kelompok pernyataan unfavorable dengan pilihan jawaban dan penilaian skor, yaitu: sangat tidak setuju diberi nilai 7 , tidak setuju diberi nilai 6 , kurang setuju diberi nilai 5, netral diberi nilai 4 , sedikit setuju diberi nilai 3 , setuju diberi nilai 2 , dan sangat setuju diberi nilai 1.

Skala Kebahagiaan Berbasis Pendekatan Indigenous Psychology oleh Anggoro dan Widhiarso (2010) terdiri dari 40 aitem yang kemudian dimodifikasi menjadi 37 aitem. Skala Kebahagiaan Berbasis Pendekatan Indigenous Psychology ini menggunakan penskalaan likert yang terdiri dari kelompok pernyataan favorable dengan pilihan jawaban dan penilaian skor, yaitu: sangat sesuai diberi nilai 5 , sesuai diberi nilai 4, netral diberi nilai 3, tidak sesuai diberi nilai 2 , dan sangat tidak sesuai diberi nilai 1. Sementara kelompok pernyataan unfavorable dengan pilihan jawaban dan penilaian skor, yaitu: sangat sesuai diberi nilai 1 , sesuai diberi nilai 2 , netral diberi nilai 3 , tidak sesuai diberi nilai 4 , dan sangat tidak sesuai diberi nilai 5 .

Metode analisis data yang digunakan dalam penelitian ini dengan menggunakan metode non parametrik yaitu Spearman. Analisis tersebut diunakan karena salah satu dari variabel penelitian tidak berdistribusi secara normal yaitu variabel kebahagiaan.

\section{HASIL}

Hasil analisis pada penelitian ini menunjukkan nilai signifikansi adalah $\mathrm{p}$ $=0,000$ lebih kecil dari $0,10(\mathrm{p}<0,10)$. Hal tersebut menunjukkan bahwa hipotesis penelitian diterima yaitu terdapat hubungan antara kebersyukuran dan kebahagiaan pada wanita yang bercerai di Aceh. Hasil analisis penelitian ini juga menunjukkan koefisien korelasi sebesar $(r)=0,650$ yang merupakan korelasi positif, artinya terdapat hubungan positif antara kebersyukuran dan kebahagiaan. Hubungan tersebut mengartikan bahwa jika semakin tinggi kebersyukuran pada wanita bercerai di Aceh maka semakin tinggi pula tingkat kebahagiaannya.

Berdasarkan hasil statistik data penelitian, analisis deskriptif secara hipotetik menunjukkan bahwa jawaban maksimal untuk variabel kebersyukuran adalah 42 , minimal 6 , nilai rata-rata 24 , dan simpangan baku 6 , sedangkan pada data empirik menunjukkan bahwa jawaban maksimal 42, minimal 16, ratarata 32,6, dan simpangan baku 5,6. Deskripsi data hasil penelitian tersebut dapat dijadikan batasan dalam pengkategorian sampel penelitian yang terdiri dari tiga kategori, yaitu tinggi, sedang dan rendah. Pembagian kategori sampel yang digunakan peneliti dalam penelitian ini menggunakan metode kategorisasi berdasarkan model distribusi normal dengan kategori jenjang. Pada penelitian ini ditemukan sebanyak 1 orang dengan persentase $0,4 \%$ pada kategori rendah, pada kategori sedang sebanyak 69 orang dengan persentase $27,9 \%$, selanjutnya kategori tinggi sebanyak 177 orang dengan persentase $71,7 \%$.

Adapun pada variabel kebahagiaan, analisis deskriptif secara hipotetik menunjukkan bahwa jawaban maksimal untuk variabel kebahagiaan 
adalah 185 , minimal 37 , nilai rata-rata 111, dan simpangan baku 24,7, sedangkan pada data empirik menunjukkan bahwa jawaban maksimal 185 , minimal 94 , rata-rata 149,6 dan simpangan baku 16,8. Berdasarkan deskripsi data hasil penelitian tersebut, maka dapat dijadikan batasan dalam pengkategorian sampel penelitian yang terdiri dari tiga kategori, rendah, sedang, dan tinggi. Pembagian kategori sampel yang digunakan oleh peneliti adalah dengan metode kategorisasi berdasarkan signifikansi perbedaan karena tidak mengasumsikan distribusi populasi yang normal (Azwar, 2013). Pada penelitian ini ditemukan sebanyak 2 orang dengan persentase $0,80 \%$ pada kategori rendah, selanjutnya kategori tinggi yaitu sebanyak 245 orang dengan persentase $99,2 \%$ dan tidak ada yang berada pada kategori sedang.

Penelitian ini dilakukan pada dua kabupaten di Aceh yaitu, Lhoksukon dan Kuala Simpang dengan jumlah sampel keseluruhan sebanyak 247 subjek yang terdiri dari, 136 subjek berasal dari kuala simpang dan 111 subjek berasal dari Lhoksukon. Data demografi yang diperoleh dari penelitian dapat dilihat pada tabel 1 di bawah (Lampiran).

Adapun penyebab perceraian subjek penelitian berbeda-beda dan pada penelitian ini dikelompokkan sesuai dengan data Mahkamah Syar'iyah dapat dilihat di gambar yang ada pada lampiran.

Gambar (pada lampiran) menunjukkan data penyebab perceraian yang dialami oleh subjek penelitian yaitu wanita bercerai di Lhoksukon dan Kuala Simpang. Adapun penyebab perceraian tertinggi didominasi oleh tidak adanya keharmonisan dengan persentase $44,5 \%$, gangguan pihak ketiga $29,9 \%$, tidak ada tanggung jawab 16,8\%, dan ekonomi $9,7 \%$

\section{DISKUSI}

individu bahagia sehingga tidak merasa kesulitan walaupun kondisi yang sedang dialami tidak sesuai dengan harapan (Puspitasari \& Nasfinoor, 2005). Penelitian sebelumnya menunjukkan bahwa terdapat hubungan yang kuat antara kebersyukuran dengan kebahagiaan (Froh, Yurkewicz \& Kashdan, 2009; Ramzan \& Rana, 2014). Kebersyukuran pada hakikatnya harus dimanifestasikan dalam perasaanperasaan positif yakni, perasaan senang dan bahagia sebagai respon atas apa yang telah diperoleh baik berupa benda, keterbatasan yang dimiliki, momen bahagia, dan juga kesulitan yang dialami dalam kehidupan (Hambali, Meiza, \& Fahmi, 2015).

Hal tersebut sesuai dengan hasil penelitian ini bahwa terdapat hubungan positif antara kebersyukuran dan kebahagiaan. Hubungan yang positif ini menunjukkan bahwa semakin tinggi kebersyukuran wanita yang bercerai maka akan semakin tinggi pula kebahagiaannya. Menurut Kristanto (2016) individu yang bersyukur akan dapat menikmati pengalaman hidup yang positif karena syukur merupakan salah satu bentuk ekspresi kebahagiaan yang sangat erat kaitannya dengan kesejahteraan. Individu yang bersyukur maka akan memunculkan ekspresi kebahagiaan (Rohma, 2013). Hal tersebut sejalan dengan penelitian ini, ditemukan sebesar $71,7 \%$ subjek memiliki kebersyukuran yang tinggi dan 99,2\% subjek memiliki kebahagiaan yang tinggi pula. Hal ini sejalan dengan hasil penelitian Nur'aeni dan Dwiyanti (2009) yang menemukan bahwa perempuan bercerai dan berubah status menjadi janda maka akan mengalami perasaan minder, malu, sedih, sakit hati, namun dapat juga merasakan lega, senang, dan bahagia. Artinya kebahagiaan datang setelah individu sukses mengatasi kesulitan yang panjang, namun tidak semua kesulitan yang 
muncul dapat memberikan efek positif seperti kebahagiaan (Mubarok, 2016).

Menurut Olson, DeFrain dan Skogrand (2010) tujuan individu menikah adalah untuk menemukan teman berbagi sepanjang hidup dan membangun keluarga (companionship). Akan tetapi, perceraian dalam pernikahan juga tidak selalu dapat dihindari. Berdasarkan hasil penelitian ini terdapat berbagai macam alasan perceraian yang dikemukakan oleh subjek penelitian, selanjutnya dikelompokkan berdasarkan faktor penyebab perceraian yang dikeluarkan oleh Mahkamah Syar'iyah sehingga didapatkan data penyebab yaitu tidak ada keharmonisan, gangguan pihak ketiga, tidak ada tanggung jawab, dan ekonomi. Hasil penelitian ini didukung oleh penelitian yang dilakukan oleh Nisfannoor dan Yulianti (2005) yang menyebutkan bahwa pihak wanita yang menuntut cerai biasanya disebabkan oleh tidak adanya kecocokan, masalah ekonomi, tidak bahagia, perselingkuhan dan juga masalah komunikasi. Pada penelitian Sari (2012) ditemukan bahwa terdapat istri yang belum memaafkan perselingkuhan yang dilakukan oleh suami akan tetapi, tetap bertahan dengan rumah tangganya tanpa menggugat cerai dikarenakan faktor finansial yaitu ketergantungan secara ekonomi dan juga faktor anak yang telah dimiliki.

Pada proses pelaksanaan penelitian, peneliti menyadari adanya kekurangan dan keterbatasan pada penelitian ini. Pertama, data pada penelitian ini dianalisis menggunakan teknik statistik non parametric sehingga hasil dari penelitian tidak dapat digeneralisasikan secara umum. Kedua, Alat ukur dianggap memiliki jumlah pernyataan yang cukup banyak yaitu 42 aitem sehingga, subjek merasa jenuh ketika mengisi. Selain itu, ada beberapa kata yang tidak dapat dipahami oleh subjek penelitian sehingga menimbulkan banyak pertanyaan. Hal tersebut dapat terjadi karena kendala pada bahasa yang digunakan. Mayoritas subjek pada penelitian ini menggunakan bahasa Aceh sebagai bahasa sehari-hari, sedangkan alat ukur dalam penelitian ini menggunakan bahasa Indonesia. Hal ini menyebabkan banyak subjek terutama yang berlokasi di Lhoksukon mengalami kesulitan saat mengisi kuesioner.

Ketiga, Proses pengumpulan data tidak dilakukan secara langsung oleh peneliti, melainkan data dikumpulkan oleh pihak Mahkamah Syar'iyah. Pihak Mahkamah Syar'iyah tidak mengizinkan mengambil data penelitian secara langsung (bertatap muka) karena kasus cerai merupakan isu sensitif di lokasi penelitian. Keempat, data demografi yang diungkap dalam penelitian ini masih terkait dengan isu perceraian (usia saat ini, usia ketika bercerai, dan usia pernikahan), namun data lainnya tidak diungkap (pendidikan, agama, dan pekerjaan). Padahal beberapa data yang tidak terungkap tersebut diprediksi pada penelitian sebelumnya memiliki kaitan dengan variabel yang diukur dalam penelitian ini (kebersyukuran dan kebahagiaan). Beberapa keterbatasan ini dapat dijadikan pertimbangan untuk penelitian selanjutnya.

\section{SIMPULAN}

Penelitian ini bertujuan untuk mengetahui hubungan kebersyukuran dan kebahagiaan pada wanita yang bercerai di Aceh. Hasil penelitian ini menunjukkan terdapat hubungan antara kebersyukuran dan kebahagiaan. Artinya semakin tinggi kebersyukuran maka semakin tinggi pula kebahagiaan. Hal ini terjadi karena dengan individu bersyukur maka akan memengaruhi kebahagiaannya. Hasil penelitian ini juga menunjukkan bahwa mayoritas wanita bercerai yang terlibat pada penelitian memiliki tingkat kebersyukuran dan kebahagiaan pada kategori tinggi. Adapun faktor utama perceraian pada penelitian ini disebabkan oleh tidak 
adanya keharmonisan dalam rumah tangga, gangguan pihak ketiga, tidak ada tanggung jawab, dan juga faktor ekonomi.

\begin{tabular}{crr}
\multicolumn{2}{c}{ Penelitian ini mengungkap } \\
konstrak psikologis & berupa
\end{tabular} kebersyukuran dan kebahagiaan pada wanita yang bercerai di Aceh, dimana sebelumnya hal ini belum pernah diteliti. Hasil penelitian ini juga melihat dampak perceraian dari segi psikologi positif. Di Aceh sendiri, perceraian dalam pandangan masyarakat masih merupakan suatu hal negatif, sehingga dengan adanya penelitian ini dapat dilihat bahwa terdapat hal positif dari perceraian. Penelitian ini juga memiliki keterbatasan berupa data pada penelitian dianalisis menggunakan teknik statistik non parametric sehingga hasil dari penelitian tidak dapat digeneralisasikan secara umum.

Pada proses pengumpulan data dalam penelitian ini, peneliti tidak melakukan secara langsung, melainkan data dikumpulkan oleh pihak Mahkamah Syar'iyah. hal tersebut dikarenakan pihak Mahkamah Syar'iyah tidak mengizinkan mengambil data penelitian secara langsung (bertatap muka) karena kasus cerai merupakan isu sensitif di lokasi penelitian. Data demografi yang diungkap dalam penelitian ini masih terkait dengan isu perceraian (usia saat ini, usia ketika bercerai, dan usia pernikahan), namun data lainnya tidak diungkap (pendidikan, agama, dan pekerjaan) yang juga memiliki kaitan dengan variabel yang diukur dalam penelitian ini (kebersyukuran dan kebahagiaan).

Disarankan bagi wanita yang bercerai untuk dapat mempertahankan tingkat kebersyukuran yang tinggi agar dapat bahagia dan optimis dalam menjalani hidup. Kepada peneliti selanjutnya diharapkan memerhatikan jumlah butir aitem yang akan diajukan kepada subjek penelitian dan mempertimbangkan kebudayaan di lokasi penelitian guna mempermudah proses ketika penelitian. Selain itu, peneliti selanjutnya juga dapat mengungkap faktor lain yang mungkin akan memengaruhi kebersyukuran dan kebahagiaan pada wanita bercerai di Aceh seperti dari segi agama, pendidikan, dan juga pekerjaan.

\section{DAFTAR PUSTAKA}

Anggoro, W. J., \& Widhiarso, W. (2010). Konstruksi dan identifikasi propertis instrumen pengukuran kebahagiaan berbasis pendekatan indigenous psychology:studi multitrait-multimethod. Jurnal Psikologi, 37(2), 176-188.

Carr, A. (2011). Positive psychology: The science of happiness and human strengths. New York: Brunner-Routledge.

Dariyo, A. (2004). Memahami psikologi perceraian dalam kehidupan keluarga. Jurnal Psikologi, 2(2), 94-100.

Dewi, N. Y., \& Sudhana, H. (2013). Hubungan antara komunikasi interpersonal pasutri dengan keharmonisan dalam pernikahan. Jurnal Psikologi Udayana, 1(1), 22-31.

Emmons, R. A., \& McCullough, M. E. (2003). Counting blessings versus burdens: an experimental investigation of gratitude and subjective wellbeing in daily life. Journal of personality and social psychology, 84(2), 377389.

Froh, J.J., Yurkewicz, C., \& Kashdan, T.B. (2009) Gratitude and subjective in early adolescence: examining gender differences. Journal Of Adolescence, 32. 633650. 
Hambali, A., Meiza, A., \& Fahmi, I. (2015). Faktor-faktor yang berperan dalam kebersyukuran (gratitude) pada orangtua anak berkebutuhan khusus perspektif psikologi Islam. Psympathic, jurnal ilmiah psikologi, 2(1), 94101.

Kristanto, E. (19-20 Februari, 2016). Perbedaan tingkat kebersyukuaran pada lakilaki dan perempuan. Dipresentasikan pada seminar ASEAN $2^{\text {nd }}$ Psychology and Humanity, Malang.

Mahkamah Syar'iyah Aceh. Diakses pada tanggal 24 November 2015, melalui http://www.msaceh.go.id.

Markam, H. J., Rhoades, G. K., Stanley, S. M., Ragan, E. P., \& Whitton, S. W. (2010). The premarital communication roots of marital distress and divorce: the first years of marriage.J Fam Psychol, 24(3), 289298.Doi:10.1037/a0019481.

McCullough, M.E., Emmons, R.A., \& Tsang, J.A. (2002). The grateful disposition: a conceptual and empirical topography. Journal of personality and social psycology, 82(1), 112-127.

Mubarok, A. (2016). Psikologi keluarga. Jawa Timur: Madani.

Mutia, E., Subandi., \& Mulyati, R. (2010). Terapi kognitif perilaku bersyukur untuk menurunkan depresi pada remaja. Jurnal intervensi psikologi, 2(1), 53-68.

Nisfannoor, M., \& Yulianti, E. (2005). Perbandingan perilaku agresif antara remaja yang berasal dari keluarga bercerai dengan keluarga utuh. Jurnal Psikologi, 3(1), 1-18.

Nur'aeni, M., \& Dwiyanti, R. (2009). Dinamika psikologis perempuan yang bercerai (studi tentang penyebab dan status janda pada kasus perceraian di Purwokerto. Psycho idea, 7(1), 11-21.

Olson, D., DeFrain, J., \& Skogrand, L. (2010). Marriages and Families Intimacy, Diversity, and Strengths (7th Edition). Boston: McGrawHill.

Papalia, D. E., Olds, S. W., \& Feldman, R. D. (2009). Human development (perkembangan manusia), Ed. 10. Penerjemah: Brian Marwensday. Jakarta: Salemba Humanika.

Patnani, M. (2012). Kebahagiaan pada perempuan. Jurnal Psikogenesis, 1(1), 5664.

Priyatno, D. (2011). Buku Saku SPSS; Analisis statistik data, lebih cepat, efesien, dan akurat. Yogyakarta: MediaKom.

Puspitasari, T., \& Nasfiannor, M. (2005). Komitmen beragaman dan subjective well-being. Journal Phronesis, 7. 73-93.

Putra, J. S. (2014). Syukur: sebuah konsep psikologi indigenous islami. Jurnal Soul, 7(2), 35-44.

Ramzan, N. \& Rana, S.A. (2014). Expression of gratitude and subjective well-being among university teachers. Middle-East Journal of Scientific Research, 21(5): 756-762.

Rohma, N. H. (2013). Hubungan antara kepuasan hidup remaja dengan bersyukur pada siswa SMAIT Abu 
Bakar boarding school Yogyakarta. Empathy Jurnal Fakultas Psikologi, 2(1), 1-16.

Rostiana., \& Koesma, R.E. (2009). Kajian awal tentang makna kebahagian: arti ciri dan cara pencapaian kebahagiaan dalam konteks budaya islam dan Kristen di Jakarta. Jurnal Psikologi, 24(2), 24-33.
Sari, K. (2012). Forgiveness pada istri sebagai upaya untuk mengembalikan keutuhan rumah tangga akibat perselingkuhan. Jurnal Psikologi Undip, 11(1), 5058.

Seligman, M. E. P. (2002). Authentic happiness: using the new positive psychology to realize your potential for lasting fulfillment. New York: The Free Press.

\section{Lampiran.}

Tabel. 1. Data Demografi Sampel Penelitian

\begin{tabular}{|c|c|c|c|c|}
\hline $\begin{array}{l}\text { Deskripsi } \\
\text { Sampel }\end{array}$ & Kategori & Jumlah & $\begin{array}{l}\text { Persentase } \\
(\%)\end{array}$ & Total \\
\hline $\begin{array}{l}\text { Rentang usia } \\
\text { saat ini }\end{array}$ & $\begin{array}{l}23-33 \text { tahun } \\
34-43 \text { tahun }\end{array}$ & $\begin{array}{l}114 \\
133\end{array}$ & $\begin{array}{l}46,15 \\
53,85\end{array}$ & $100 \%$ \\
\hline $\begin{array}{l}\text { Rentang usia } \\
\text { ketika bercerai }\end{array}$ & $\begin{array}{l}20-25 \text { tahun } \\
26-30 \text { tahun } \\
31-35 \text { tahun } \\
36-40 \text { tahun }\end{array}$ & $\begin{array}{l}19 \\
79 \\
63 \\
86\end{array}$ & $\begin{array}{l}7,69 \\
31,98 \\
25,50 \\
34,82\end{array}$ & $100 \%$ \\
\hline $\begin{array}{l}\text { Rentang usia } \\
\text { pernikahan saat } \\
\text { bercerai }\end{array}$ & $\begin{array}{l}5-10 \text { tahun } \\
11-15 \text { tahun } \\
16-20 \text { tahun }\end{array}$ & $\begin{array}{l}131 \\
69 \\
47 \\
\end{array}$ & $\begin{array}{l}53,04 \\
27,94 \\
19,02 \\
\end{array}$ & $100 \%$ \\
\hline $\begin{array}{l}\text { Tahun } \\
\text { perceraian }\end{array}$ & $\begin{array}{l}2013 \\
2014 \\
2015 \\
\end{array}$ & $\begin{array}{l}4774 \\
126\end{array}$ & $\begin{array}{l}19,03 \\
29,96 \\
51,01 \\
\end{array}$ & $100 \%$ \\
\hline Jumlah Anak & $\begin{array}{l}1 \text { orang } \\
2 \text { orang } \\
3 \text { orang } \\
4 \text { orang } \\
5 \text { orang }\end{array}$ & $\begin{array}{l}47 \\
79 \\
70 \\
35 \\
16\end{array}$ & $\begin{array}{l}19,03 \\
31,98 \\
28,34 \\
14,17 \\
6,48\end{array}$ & \\
\hline Putusan Cerai & $\begin{array}{l}\text { Mahkamah Syar'iyah } \\
\text { Kuala Simpang }\end{array}$ & 136 & 55,06 & $100 \%$ \\
\hline & $\begin{array}{l}\text { Mahkamah Syar'iyah } \\
\text { Lhoksukon }\end{array}$ & 111 & 44,94 & \\
\hline
\end{tabular}


Data Penyebab Perceraian

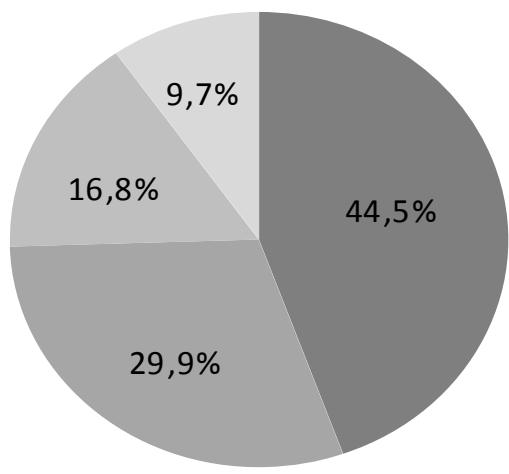

- Tidak Ada

Keharmonisan

- Gangguan Pihak Ketiga

Tidak Ada Tanggung

Jawab

Ekonomi 